A solar pond of $200 \mathrm{~m}^{2}$ area is much smaller than the economically optimum size, because of the relatively large cost of the retaining walls. In an application requiring a $2,000 \mathrm{~m}^{2}$ area-such as a pond for a group of houses, apartments, or for agricultural uses on a large farm-the energy cost would fall to perhaps $\$ 0.010$ per $\mathrm{kW}-\mathrm{hr}$ thermal.

One of the major items in these cost estimates, comprising nearly half of the total, is the salt. Locations near salt-works (where most previous solar-pond experiments have been done) allow substantial cost reduction.

It must of course be kept in mind that the preceding estimates of cost and heat energy available from solar ponds, although based on the data in hand, have yet to be confirmed in practice by continuous operation of a full-scale pond over a period of years. But these estimates are highly encouraging, and salt-gradient solar ponds now appear to be very promising systems for solar energy collection and storage. We may hope that the additional information needed for more definitive evaluation will be provided soon by experiments now in progress.

\section{SUMMARY}

Salt-gradient solar ponds function as systems to collect and store solar energy. The upper zone of the pond is rendered non-convective by the salt gradient and serves as a partially transparent insulator, permitting some of the incident solar energy to penetrate to the bottom and heat the lower zone to a temperature as high as $95^{\circ} \mathrm{C}$. A pond $3 \mathrm{~m}$ deep and $150 \mathrm{~m}^{2}$ in area is expected to provide all of the winter heat required by a house of the same area in Columbus, Ohio.

Solar ponds occur in Nature. Research on artificial solar ponds was first begun in Israel in 1958 and some research has since been done in other countries. Recent results obtained by the author and collaborators indicate that solar ponds will be simple to operate and will provide low-temperature heat at a cost of perhaps $\$ 0.010$ per $\mathrm{kW}$-hr thermal. Experiments to obtain more definitive cost information are now in progress.

\section{References}

Anderson, G. C. (1958). Some limnological features of a shallow saline meromictic lake. Limnol. Oceanogr., 3, 259-70, illustr.

Eliseyev, V. N., Usmanov, Y. U., Teslenko, L. N. (1971). Theoretical investigation of the heat regime in a saltwater solar pond. Geliotekhnika (Heliotechnology), 7, p. 17.

Eliseyev, V. N., Usmanov, Y. U., Umarov, G. Y. (1973). Determining the efficiency of a salt solar pond. Geliotekhnika (Heliotechnology), 9, p. 44.

Hirschmann, J. R. (1970). Salt flats as solar-heat collectors for industrial purposes. Solar Energy, 13, pp. 83-97, illustr.

JAIN, G. C. (1973). Heating of Solar Pond. Proc. Int. Congr.: The Sun in the Service of Mankind, Paris, sponsored by UNESCO and others, Paper EH. 61, 10 pp., illustr.

KALECSINSKY, A. VON (1902). Über die ungarischen warmen und heissen Kochalzseen als natürliche Wärmeaccumulatoren. Ann. Physik IV, 7, pp. 408-16.

Melack, J. M. \& Kilham, P. (1972). Lake Mahega: a mesotrophic, sulphato-chloride lake in western Uganda. African Journal of Tropical Hydrobiology and Fisheries, 2, pp. 141-50, illustr.

Nielsen, C. E. \& RABL, A. (1975). Operation of a Small Saltgradient Solar Pond. Paper presented at 1975 meeting, International Solar Energy Society, Los Angeles, California: 15 pp., illustr. (mimeogr.).

Niflsen, C. E., Rabl, A., Watson, J. \& Weiler, P. (in press). Maintenance of Salt Concentration Gradient in Solar Ponds. (To be published: typescript of 15 pp., illustr., available from C. E. Nielsen, Department of Physics, Ohio State University, Columbus, Ohio 43210.)

RABL, A. \& NiELSEN, C. E. (1975). Solar ponds for space heating. Solar Energy, 17, pp. 1-12, illustr.

TABOR, H. (1963). Large-area solar collectors for power production. Solar Energy, 7, pp. 189-94, illustr.

TABOR, H. (1966). Solar ponds. Science Journal, 66 (June 1966), pp. $66-71$, illustr.

Umarov, Y. U., Eliseyev, V. N. \& Umarov, G. Y. (1971). Investigating the heat regime in a saltwater solar pond. Geliotekhnika (Heliotechnology), 7, p. 24 (transl.).

Usmanov, Y. U., UMarov, G. Y. \& ZaKhidov, R. A. (1969). Salt ponds as accumulators of solar energy. Geliotekhnika (Heliotechnology), 5, p. 49 (transl.).

Wilson, A. T. \& Wellman, H. W. (1962). Lake Vanda: an antarctic lake. Nature (London), 196, pp. 1171-3, illustr.

\title{
Half the Surviving Orang-utans in Sumatra Doomed to Lose Their Habitats
}

Fully half of the surviving Orang-utans (Simia satyrus) in Sumatra are doomed to lose their natural rain-forest habitat within ten to fifteen years through commercial logging and primitive agriculture, according to a report received recently by the World Wildlife Fund. A survey by a Dutch biologist, H. D. Rijksen, and his wife, has indicated a population of about 15,000 Orang-utans in Sumatra-which, with Borneo, is the only area where this great ape is found in the wild.

Mr Rijksen declared that there were no signs that the loss of their habitat by 7,500 or more Orang-utans could be prevented, adding that this emphasized the importance of the $6,000 \mathrm{~km}^{2}$ Gunung Leuser Reserve, west of Medan, as the only possible refuge for the Orang-utan and other unique south-east Asian species such as the Sumatran
Rhinoceros (Dicerorhinus (Didermocerus) sumatrensis) and the Sumatran Tiger (Felis tigris sumatrae).

The World Wildlife Fund is working with the Indonesian authorities to ensure the future of the Gunung Leuser Reserve through scientific surveys and development of management plans. Two stations have been established for the rehabilitation of young Orang-utans that have been confiscated from people who were illegally keeping them as pets. These Orang-utans are reintroduced slowly to wild communities into which they are gradually absorbed.

PeTER F. R. JACKSON, Director of Information World Wildlife Fund 1110 Morges Switzerland. 